\title{
Durability and compressive strength of blast furnace slag-based cement grout for special geotechnical applications
}

\author{
J.M. Ortega ${ }^{\mathrm{a} \bowtie}$, J.L. Pastor ${ }^{\mathrm{a}, \mathrm{b}}$, A. Albaladejo ${ }^{\mathrm{a}}$, I. Sánchez ${ }^{\mathrm{a}}$, M.A. Climent ${ }^{\mathrm{a}}$ \\ a. Universidad de Alicante (Alicante, España) \\ b. Consulteco, S.L. (Alicante, España) \\ \jm.ortega@ua.es
}

Received 17 October 2012

Accepted 10 January 2014

Available on line 11 March 2014

\begin{abstract}
Special foundations, most prominently micropiles and soil anchors, are frequently used in construction today. In Spain, the grout for these special technical applications is generally prepared with portland cement, although the codes and standards in place stipulate only the minimum compressive strength required, with no mention of cement type. Those texts also establish a range of acceptable water:cement ratios. In the present study, durability and compressive strength in cement grout prepared with blast furnace slag cement at different $\mathrm{w} / \mathrm{c}$ ratios are characterised and compared to the findings for a reference portland cement grout. The results show that slag grout exhibits greater durability than the portland cement material and complies with the compressive strength requirements laid down in the respective codes.
\end{abstract}

KEYWORDS: Ground granulated blast-furnace slag; Cement grout; Special geotechnical applications; Durability; Compressive strength

Citation / Citar como: Ortega, J.M.; Pastor, J.L.; Albaladejo, A.; Sánchez, I.; Climent, M.A. (2014). Durability and compressive strength of blast furnace slag-based cement grout for special geotechnical applications. Mater. Construcc. 64 [313], e003 http://dx.doi.org/10.3989/mc.2014.04912

RESUMEN: Caracterización de las propiedades de durabilidad y resistencia a compresión de lechadas de cemento con escoria de alto horno para trabajos geotécnicos especiales. Actualmente es muy frecuente el empleo de cimentaciones especiales, entre las que destacan los micropilotes y los anclajes. En España, las lechadas de cemento para estos trabajos geotécnicos especiales se preparan habitualmente con cemento Portland, aunque las diferentes normativas al respecto no restringen el tipo de cemento a emplear, siempre que se alcance una determinada resistencia a compresión. Respecto a la dosificación de las lechadas, la normativa permite emplear diferentes relaciones agua/cemento dentro de un determinado rango. En vista de ello, en este trabajo se han caracterizado las propiedades de durabilidad y resistencia a compresión de lechadas de cemento preparadas con un cemento con escoria de alto horno y con diferentes relaciones a/c, tomando como referencia de comportamiento lechadas de cemento Portland. El uso de un cemento con escoria conlleva una mejora en la durabilidad de las lechadas, cumpliendo los requisitos de resistencia a compresión establecidos por la normativa.

PALABRAS CLAVE: Escoria de alto horno; Lechadas de cemento; Trabajos geotécnicos especiales; Durabilidad; Resistencia a compresión

Copyright: (C) 2014 CSIC. This is an open-access article distributed under the terms of the Creative Commons Attribution-Non Commercial (by-nc) Spain 3.0 License.

\section{INTRODUCTION}

Special foundations for buildings and civil works are becoming increasingly common in construction today. The use of one such special geotechnical application, micropiles, has grown significantly in recent years in light of its adaptability to all manner of terrains and its aptness for underpinning existing foundations, among others $(1,2)$. Micropiles are cylindrical members with diameters of under 
$300 \mathrm{~mm}$, drilled and grouted with cement grout or mortar injected in one or two phases, reinforced with steel tubing and sometimes strengthened with one or several ribbed bars $(1,2)$. Figure 1a contains elevation and cross-section sketches of a micropile with steel tube reinforcement.

In Spain cement grout for micropiles is usually prepared with (type I) portland cement, although no cement type is explicitly specified in the Ministry of Internal Development's guide for designing and building micropiles in road works (2), whose provisions in this regard are confined to minimum compressive strength and cement strength class. Similarly, the Spanish / European standard for micropile construction, UNE-EN 14199:2006 (3), and the US Department of Transportation, Federal Highway Administration's manual entitled Micropile - Design and Construction Guidelines (FHWA-SA-97-070) (1) lay down the minimum compressive strength for micropiles, but not the type of cement to be used. Cement grout for micropiles is generally prepared with a w:c ratio of 0.5 , although the aforementioned codes and standards (1-3) envisage a range of acceptable ratios.

Soil anchors are another type of special geotechnical application. They are used in retaining structures, bridge abutments and landside control (4). These members, which transfer surface tensile stress to the undersoil (4), consist essentially of a head and a free and a fixed anchor $(4,5)$, as shown in Figure $1 \mathrm{~b}$. Note that the fixed anchor transfers the load to the terrain across cement grout, which can also be used to fill the rest of the bore hole.

As in micropiles, the cement grout for soil anchors is normally prepared with (type I) portland cement, although neither standard UNE-EN 1537:2001 (5) nor the Spanish Ministry of Internal
Development's guide for designing and building soil anchors in road works (4) contains any requirement on the type of cement, confining their specifications to a minimum strength class and the obligation to comply with the design compressive strength. The w:c ratio specifications for soil anchor grout are also expressed as a range of values (4).

A number of environmental benefits derive from the use of active cement additions to manufacture concrete. One of the foremost such additions is blast furnace slag, whose effects on the properties of cement-based materials are the object of considerable research (6). Several studies have shown that mortars and concretes prepared with cements containing blast furnace slag perform well in many applications (6-8), particularly for structures in marine environments (9-11). This improvement is related to the hydraulic properties of blast furnace slag. The products formed during slag hydration induce microstructural refinement in the mortar and concrete $(6,7,12)$. Consequently, given the relationship between microstructure and durability in cement-based materials $(13,14)$, blast furnace slag additions reduce their permeability and enhance their resistance to aggressive agent ingress $(8,15)$.

Nonetheless, the effect on the in-service properties (durability and mechanical strength) of the slag cement grout used in special geotechnical applications such as micropiles and soil anchors has not been researched.

The characterisation of cement grouts for soil anchors and micropiles is of cardinal importance for the prevention of reinforcement corrosion. Moreover, the fact that in soil anchors and micropiles the reinforcing steel is embedded in cement grout (cement paste) distinguishes these members

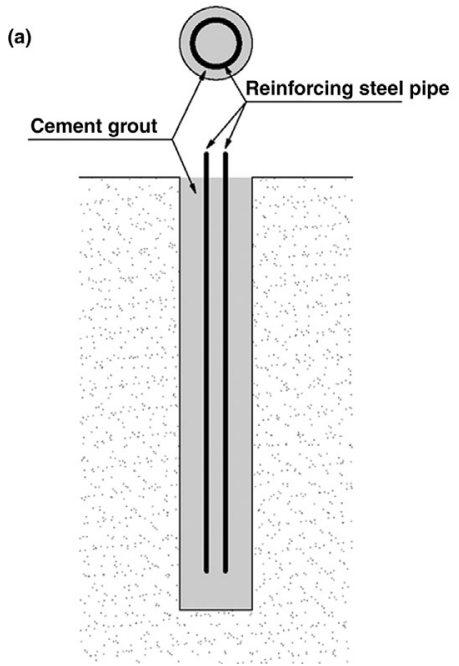

(b)

FIGURE 1. (a) Elevation view and cross-section of micropile with steel tube reinforcement (1-3); (b) Main constituent parts and elements of a soil anchor $(4,5)$. 
from other civil engineering structures, where it is embedded in concrete. The study of the durability of cement grout, particularly blast furnace slagbased grout, is consequently highly pertinent. In this study, effective porosity was the parameter used to assess durability, for water is the main vehicle for the ingress of aggressive agents in cement-based materials (13). Grout chloride resistance was also analysed, inasmuch as these ions are among the primary inducers of steel corrosion, particularly in micropiles and soil anchors in contact with aggressive water or soil.

The mechanical property studied was compressive strength, since as noted above, this is the main parameter used in codes and standards for determining whether a cement is apt for such applications.

This research aimed to characterise durabilityrelated properties and compressive strength in cement grout prepared with a commercial cement blended with blast furnace slag at different $\mathrm{w}: \mathrm{c}$ ratios, for use in micropiles and soil anchors. Portland cement grouts made with the same w:c ratios were used as a control. Because the grout in these applications hardens in contact with the surrounding terrain, exposing it to possible aggressive agents, its properties were characterised from very early ages ( 2 days) and up to 90 days.

\section{EXPERIMENTAL}

\subsection{Sample preparation}

Grouts were prepared with two commercial cements, a type I $52.5 \mathrm{R} / \mathrm{SR}$ portland cement, and a cement blended with blast furnace slag, type III/B 42.5 L/SR, respectively labelled CEM I and CEM III, adopting the terminology used in Spanish / European standard UNE-EN 197-1:2000 (16). The clinker replacement rate in CEM III ranged from 66 to $80 \%$. Both cements were compliant with reference guide $(2,4)$ minimum strength class requirements (42.5 MPa).

The w:c ratios used to prepare the grouts were $0.4,0.45,0.5$ and 0.55 . The Spanish guide for designing and building micropiles in road works (2) envisages w:c ratios of from 0.4 to 0.55 , while Spanish / European standard UNE-EN 14199:2006 (3) specifies that the ratio must be lower than 0.55. Manual FHWA-SA-97-070 (1), in turn, stipulates that the $\mathrm{w}: \mathrm{c}$ ratio in grout for micropiles must lie between 0.4 and 0.5 . The Spanish guide for the design and construction of soil anchors in road works (4) calls for a w:c ratio of from 0.4 to 0.6 , unless the site supervisor substantiates some other value. It also provides that in grout used as anti-corrosion protection for the reinforcement the w:c ratio may not be higher than 0.4. The w:c ratios studied here, then, lie within the limits established by the existing codes and standards.
Different types of specimens were prepared as recommended in Spanish / European standard UNE-EN 196-3:2005 (17). Cylindrical specimens $10 \mathrm{~cm}$ in diameter and $15 \mathrm{~cm}$ high were moulded and then cut into disks 1 to $5 \mathrm{~cm}$ thick to study post-submersion water absorption and determine effective porosity. Other cylindrical specimens were cast to diameters of 10 and $15 \mathrm{~cm}$ and a height of $30 \mathrm{~cm}$. The $10-\mathrm{cm}$ diameter samples were used to study the variations in electrical resistivity and the 15-cm specimens to determine compressive strength and the penetration of water under pressure. Lastly, prismatic specimens $4-\mathrm{cm}$ square by $16-\mathrm{cm}$ deep were also prepared (UNE-EN 196-1:2005 (18)) to compare their compressive strength to the strength found for the $15-\mathrm{cm}$ diameter $\times 30-\mathrm{cm}$ high specimens. After casting, the specimens were stored in a humidity chamber $\left(20^{\circ} \mathrm{C}\right.$ and $\left.95 \% \mathrm{RH}\right)$ for 24 hours. They were subsequently removed from the moulds, cut into disks (as appropriate) and, except the 15-cm diameter $\times 30$-cm high specimens, submerged in distilled water until the test date. The latter were stored in a humidity chamber as specified in Spanish / European standard UNE-EN 12390-2:2001 (19) as recommended for such specimens in the Spanish guide for designing and building micropiles in road works (2).

\subsection{Electrical resistivity}

This parameter is an indirect measure of connectivity and pore size in a material. Here it was determined in cement paste specimens using the Wenner four-point test (20) described in Spanish standard UNE 83988-2:2008 (21). This very well known method is widely used in cement-based materials $(20,22)$. Specimen electrical resistivity was measured directly on a Proceq analyser.

\subsection{Absorption after submersion}

Absorption was determined as described in ASTM standard C642-90 (23). The samples were extracted from the $1 \mathrm{~cm}$ thick disks. Eight samples were tested per cement type and w:c ratio. Tests were conducted on 2-, 7-, 14-, 21-, 28-, 60- and 90-day specimens.

\subsection{Effective porosity}

This parameter was determined with the capillary absorption method described in Spanish standard UNE 83982:2008 (24), based on the Fagerlund test for determining capillarity in cement-based materials. Ten-centimetre diameter cylindrical specimens measuring $5 \mathrm{~cm}$ thick were tested by sealing the bottom half of the side surface of the specimen with adhesive tape to ensure that only one of the flat surfaces of the specimen was in contact with the water (Rilem TC 116-PCD (25)). 
According to the recommendations on specimen conditioning for capillarity tests contained in the literature, the degree of water saturation used should be the equilibrium saturation at $75 \%$ relative humidity, drying should be conducted at $50{ }^{\circ} \mathrm{C}$ and moisture should be redistributed $(25,26)$. Other codes (27) prescribe full drying at $105^{\circ} \mathrm{C}$, however. Although the former procedure entails a lower risk of microstructural alterations due to the lower drying temperature, its implementation calls for fairly long test times (on the order of at least one month for each condition tested). Given the large number of samples analysed in this study and the need to determine all the porosity-related properties at approximately the same time, the samples were dried at $105^{\circ} \mathrm{C}$ for 12 hours and from then on through the beginning of the test 12 hours later, they were stored in air-tight containers with silica gel. This procedure has been used in the past for fly ash- and blast furnace slag-blended cement (28).

Effective porosity was determined from the following equation [1], further to standard UNE 83982: 2008 (24):

$$
\varepsilon_{\mathrm{e}}=\frac{\mathrm{Q}_{\mathrm{n}}-\mathrm{Q}_{0}}{\mathrm{~A} \cdot \mathrm{h} \cdot \delta_{\mathrm{a}}}
$$

where: $\varepsilon_{\mathrm{e}}$ is effective porosity; $\mathrm{Q}_{\mathrm{n}}$ is the specimen mass $(\mathrm{g})$ at saturation at the end of the test; $\mathrm{Q}_{0}$ is the pre-test specimen mass (g); A is the area of the section of the specimen in contact with the water $\left(\mathrm{cm}^{2}\right)$; h is specimen height $(\mathrm{cm})$; and $\delta_{\mathrm{a}}$ is water density $\left(1 \mathrm{~g} / \mathrm{cm}^{3}\right)$.

Three specimens were tested per cement type and w:c ratio. Tests were conducted on 2-, 14-, 28- and 90-day specimens.

\subsection{Water penetration under pressure}

This test was conducted on $15-\mathrm{cm}$ diameter, 30-cm high cylinders as recommended in Spanish / European standard UNE-EN 12390-8:2009 (29), i.e., by applying water to the specimens at a pressure of $500 \pm 50 \mathrm{kPa}$ for $72 \pm 2$ hours. Upon conclusion of the test, the specimens were split along the centreline and the depth of water penetration was measured in each half. Although this test is actually designed for hardened concretes cured under water (29), it was applied here to the cement grout because the standards on micropiles (2) and soil anchors (4) refer to the provisions of Spanish Structural Concrete Code EHE-08 for characterising most grout properties (30).

Furthermore, since standard UNE-EN 123908:2009 (29) specifies no pre-trial conditioning procedure for the specimens, in this study they were initially stored in an oven at $60{ }^{\circ} \mathrm{C}$ for 72 hours prior to the test. Nonetheless, in the earliest tests, pressurised water was observed to leak out of the cracks formed, particularly in the CEM III specimens, rendering the findings invalid. Consequently, the specimens were ultimately conditioned by storage for 72 hours at a temperature of $20 \pm 2{ }^{\circ} \mathrm{C}$ and relative humidity of $50 \%$. Two 28 - and two 90 -day specimens were tested for each type of cement and $\mathrm{w}: \mathrm{c}$ ratio, and the mean and maximum depths of the water penetration front were recorded.

\subsection{Determination of the steady state $\left(D_{s}\right)$ chloride diffusion coefficient based on resistivity}

The measure of electrical resistivity of cement paste or concrete is an indirect method for determining its steady state chloride diffusion coefficient (D) $(20,31)$. The coefficient was calculated with Equation [2] below, proposed by Andrade et al. (31):

$$
\mathrm{D}_{\mathrm{s}}=\frac{2 \cdot 10^{-10}}{\rho}
$$

where: $\mathrm{D}_{\mathrm{s}}$ is the steady state chloride diffusion coefficient $\left(\mathrm{m}^{2} / \mathrm{s}\right)$ and $\rho$ is the electrical resistivity of the specimen $(\Omega \cdot \mathrm{m})$.

In this study, the variation in the diffusion coefficient $\left(D_{s}\right)$ was monitored through the age of 90 days.

\subsection{Determination of compressive strength}

Strength was found for both the cylindrical specimens measuring $15 \mathrm{~cm}$ in diameter $\times 30 \mathrm{~cm}$ high (standard UNE-EN 12390-3:2003 (32)) and for prismatic specimens $4 \mathrm{~cm}$ square $\times 16 \mathrm{~cm}$ deep (standard UNE-EN 196-1:2005 (18)). The reason for determining this parameter in cylindrical specimens as well as in the prismatic specimens generally used was that Spanish / European codes on micropile construction $(2,3)$ provide that simple compressive strength must be found for grout on cylindrical specimens with a height-diameter ratio of 2. US manual FHWA-SA-97-070 (1), in turn, stipulates that the compressive strength of grout used to build micropiles should be determined on 5 -cm cubic specimens, which were not tested in this study. Nonetheless, the strength values found for the $4 \times 4 \times 16-\mathrm{cm}$ specimens further to the procedure described in standard UNE-EN 196-1 (18), whereby loads are applied across $40-\mathrm{mm}$ square plates, could well be a valid reference for the strength that would be observed in $50-\mathrm{mm}$ cubic specimens. The legislation on soil anchors $(4,5)$, in turn, stipulates no specific geometry for the specimens to be used in compressive strength tests.

Further to the Spanish guide for designing and building micropiles in road works (2) and standard UNE-EN 14199 (3), 28-day (or earlier if the micropile is loaded prior to that age) compressive strength should be at least $25 \mathrm{MPa}$ in cylindrical specimens and the 7-day strength must be greater than or 


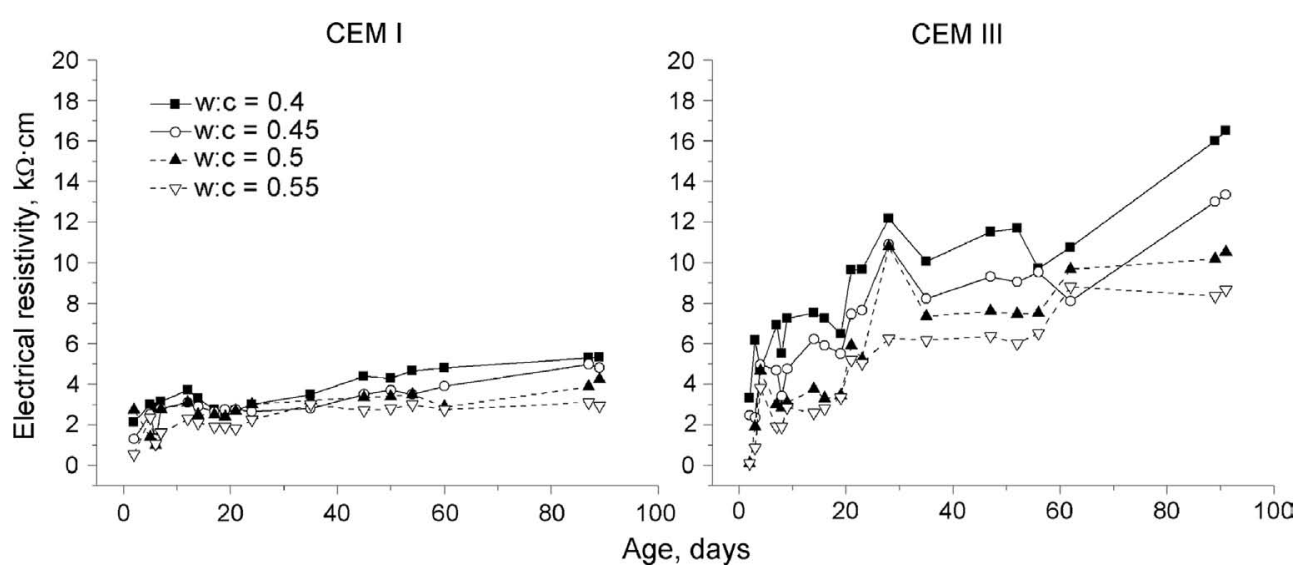

FIGURE 2. Electrical resistivity in CEM I and CEM III specimens.

equal to $60 \%$ of the 28 -day requirement. Manual FHWA-SA-97-070 (1) calls for compressive strength of 28 to $35 \mathrm{MPa}$ in the 28-day cubic specimens described above. For soil anchors, the Spanish guide for designing and building soil anchors in road works (4) provides that grout compressive strength is to be defined in the design. The protocol for monitoring soil anchor construction laid down in the aforementioned guide (4) suggests that compressive strength should be determined in 7- and 28-day grout.

In light of the foregoing, in this study compressive strength was determined on the 7- and 28-day specimens prepared as described above. Three prismatic and two cylindrical specimens were tested per cement type and $\mathrm{w}: \mathrm{c}$ ratio.

\section{RESULTS}

\subsection{Electrical resistivity}

The variation in this parameter in the CEM I and CEM III grouts is shown in Figure 2. The values rose with time in all the specimens studied, although more in the CEM III than in the CEM I grouts. In the 90-day specimens, the highest resistivity values were recorded for the CEM III grouts, a finding that concurred with earlier reports (33).

\subsection{Absorption after submersion}

The findings for this parameter are depicted in Figure 3. At early ages, the post-submersion absorption values were lower in grouts CEM I than CEM III. While this parameter barely varied over time in the CEM I specimens, in the CEM III samples absorption declined through the $28^{\text {th }}$ day and remained essentially flat thereafter. The postsubmersion absorption values were very similar in the 90-day specimens for the two types of cement.

\subsection{Effective porosity}

Further to the porosity findings for grouts CEM I and CEM III shown in Figure 4, this parameter declined with age in both materials. In the CEM I grout, effective porosity was fairly low in the

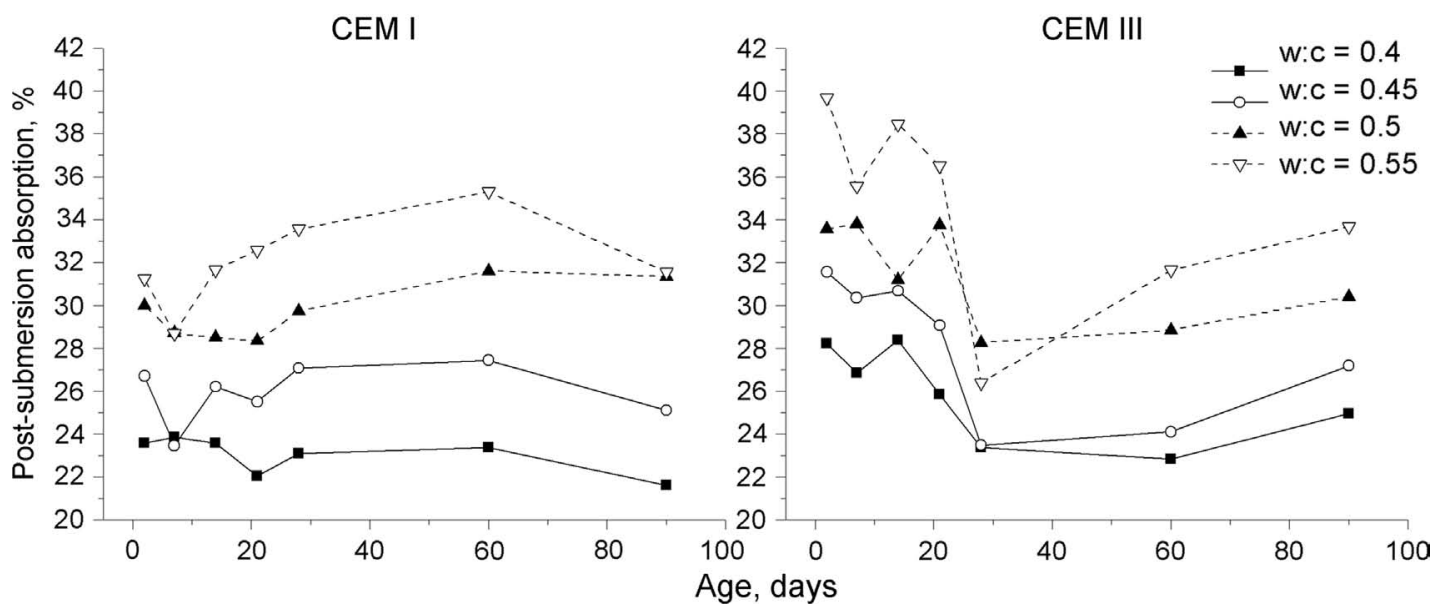

FIgURE 3. Post-submersion water absorption in grouts CEM I and CEM III. 


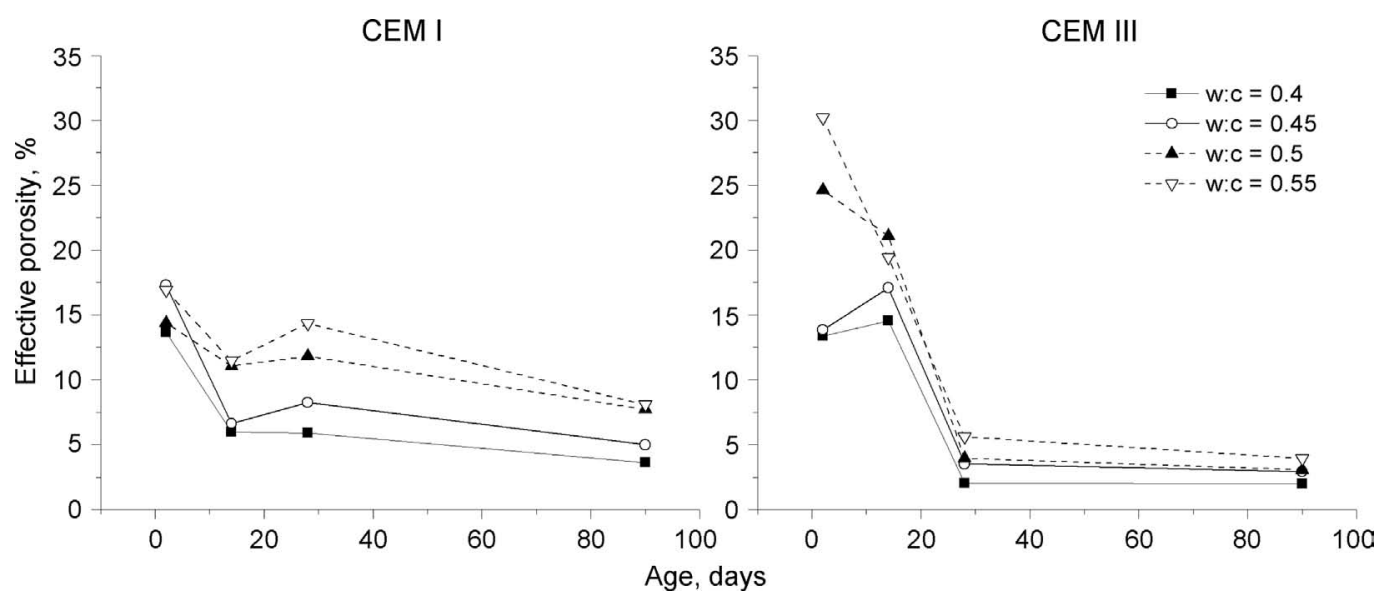

FIgURE 4. Effective porosity in grouts CEM I and CEM III.

2- and 14-day specimens. While higher porosity was observed for CEM III grout at those ages, between 14 and 28 days porosity declined abruptly in CEM III, to values lower than recorded for CEM I.

\subsection{Water penetration under pressure}

The results of this test for each type of cement and w:c ratio are depicted in Figure 5. Note that in both the 28- and 90-day specimens, at the w:c ratios studied, CEM I exhibited higher mean and maximum penetration depths than CEM III grout.

\subsection{Steady state chloride diffusion coefficient based on resistivity}

Further to the findings for CEM I and CEM III shown in Figure 6, this coefficient declined with hardening time in both types of cement grout. Generally speaking, the diffusion coefficient was
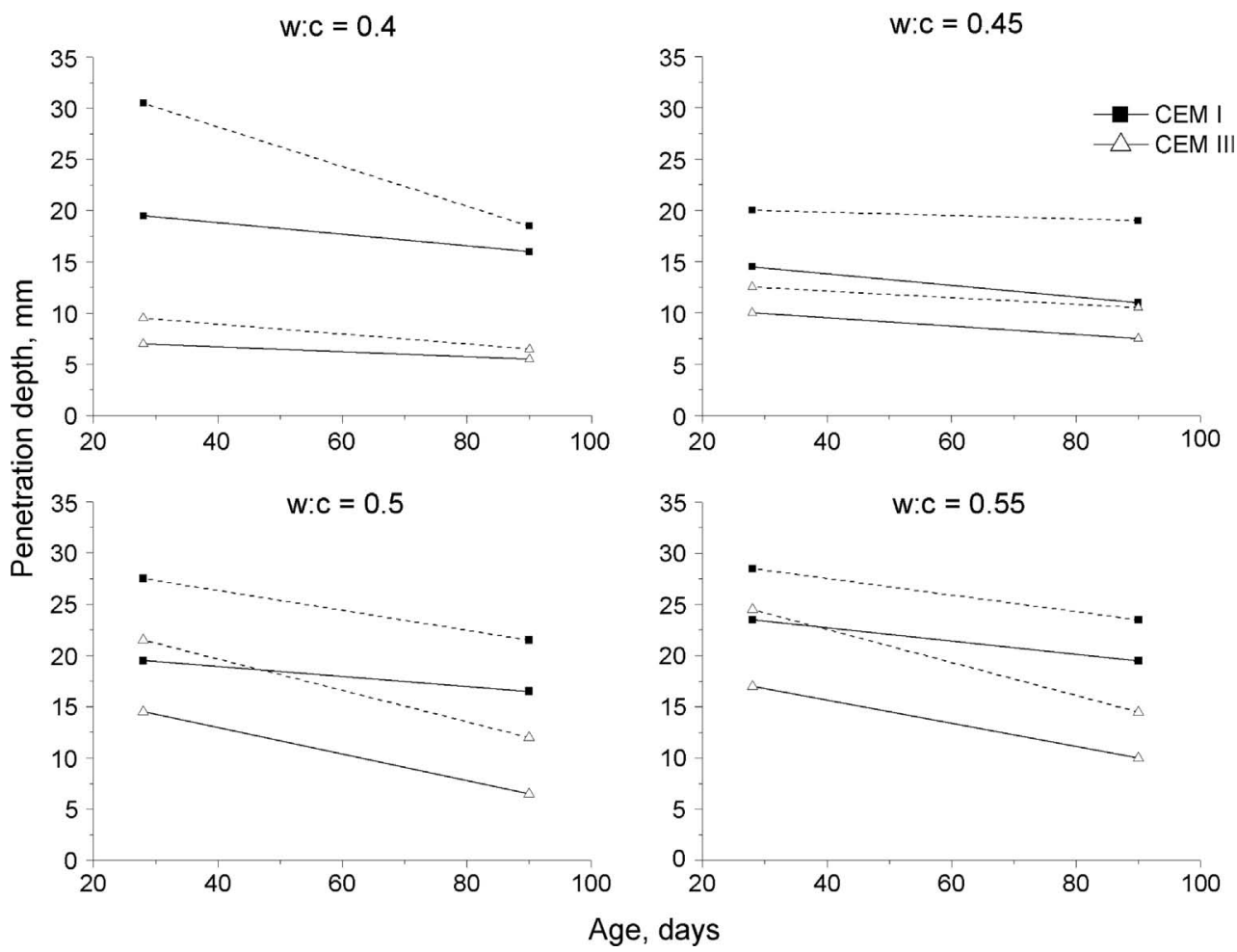

FIGURE 5. Depth of water penetration under pressure in CEM I and CEM III specimens, by w:c ratio (solid lines denote mean and dotted lines maximum penetration) 


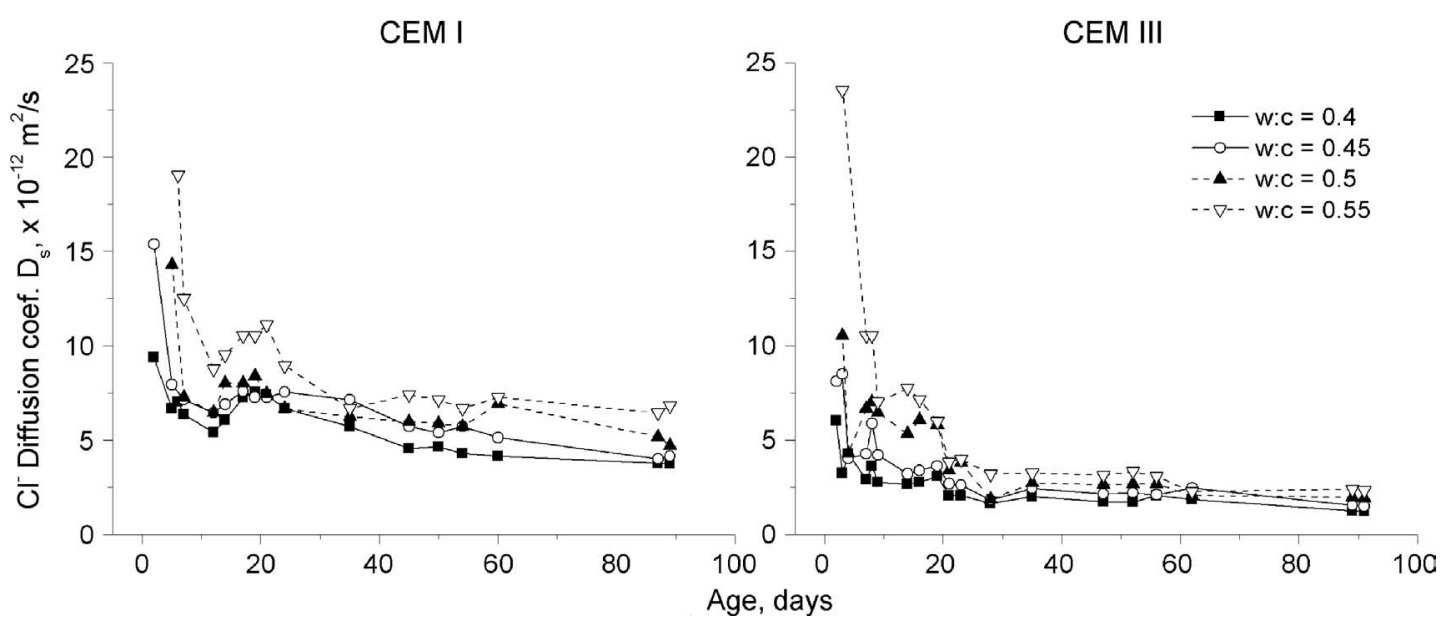

FIGURE 6. Steady state chloride diffusion coefficient found from the electrical resistivity of the samples, for grouts CEM I and CEM III.

lower in grout CEM III than in CEM I at most of the ages studied.

\subsection{Compressive strength}

Figure 7 shows the compressive strength findings for cylindrical and prismatic specimens made with both types of cement. As a rule, the 28-day compressive strength was slightly higher in the CEM I than in the CEM III grout, when measured on both cylindrical and prismatic specimens.

\section{DISCUSSION}

\subsection{Durability-related properties}

Electrical resistivity readings furnish information on pore connectivity and size in materials, both of which parameters are associated with durability. Electrical resistivity rose with time for both types of cement studied (see Figure 2), denoting the progressive refinement of the pore network as a result of ongoing clinker and slag hydration $(6,28)$. While
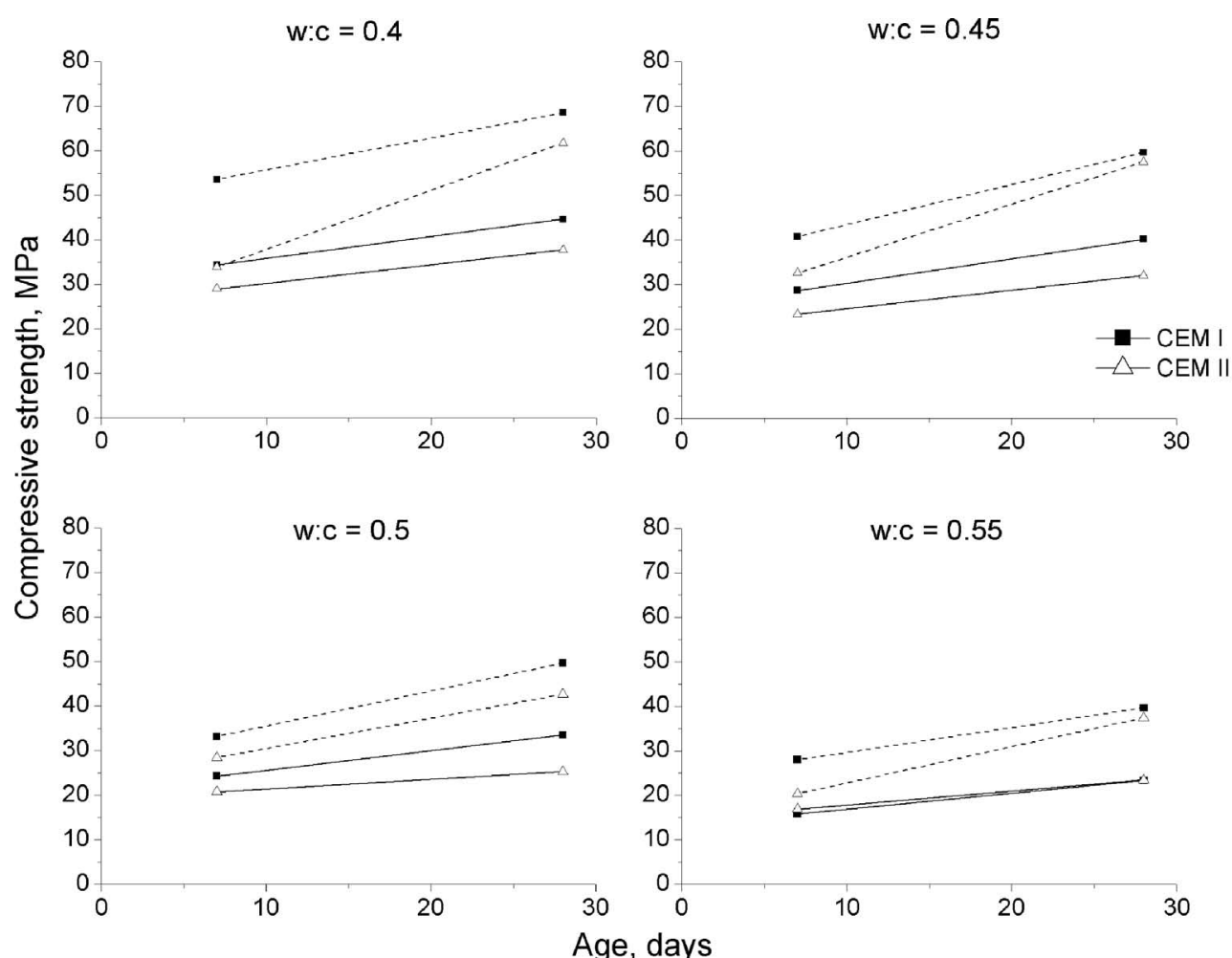

FIGURE 7. Compressive strength for grouts CEM I and CEM III by w:c ratio (dotted lines show results for 4-cm square, 16-cm deep prismatic specimens; solid lines for 15-cm diameter, 30-cm high cylindrical specimens). 
at early ages electrical resistivity was similar in the two cement grouts, at later ages higher values were recorded for CEM III than for CEM I. These findings may be related to the substantial microstructural refinement attendant upon slag hydration $(6,7,28)$, in which additional C-S-H phases form (12), giving rise to a more compact pore network. Moreover, the fact that early age electrical resistivity values were similar in the two types of cement studied, but slightly higher for CEM I at w:c ratios of 0.5 and 0.55 may be attributable to the slower reaction rate in slag hydration $(7,34)$.

Post-submersion absorption furnishes information on the pore volume in a material. While at early ages, the post-submersion absorption values were higher in CEM III than in CEM I grout (see Figure 3), absorption was similar in the two types of cement in the longer term. The findings therefore indicate that in the short term the total pore volume was higher in the CEM III grout, whereas the longterm volume was very similar in the two materials.

The aforementioned findings appear to show that the use of cements with a high blast furnace slag content in cement grout for soil anchors and micropiles leads to a more refined microstructure in the hardened grout than observed in the portland cement-based material, although the pore volume was not observed to decline significantly. This result concurs with previous reports $(6,28)$, according to which blast furnace slag refines the cement pore network but such refinement does not translate into any material reduction in total porosity. The findings also indicate that the $\mathrm{w}$ :c ratio scantly affects grout microstructure other than as regards the foreseeable rise in pore volume at higher ratios.

Effective porosity, in turn, is directly related to the volume of pores accessible to water and therefore to aggressive agents such as chloride ions, which may corrode the steel used to reinforce micropiles and soil anchors. At early ages, effective porosity was higher in the CEM III than in the CEM I specimens (see Figure 4). After 28 days, however, porosity was substantially lower in the former. The high short-term effective porosity observed for CEM III may be related to the slower reaction rate that characterises slag hydration, as discussed earlier in connection with the electrical resistivity and absorption findings. This would mean that at very early ages, the microstructure of CEM III would be less refined than at older ages and the volume of pores accessible to water would be greater.

Pre-trial specimen conditioning may have also affected these short-term effective porosity findings. Such conditioning included oven-drying at $105^{\circ} \mathrm{C}$, which may have induced shrinkage cracks in the grout $(35,36)$. The appearance of these cracks, in combination with a scantly refined early age pore network, might explain the high effective porosity values observed for the CEM III material. At longer hardening times, these adverse consequences of high temperature drying would be mitigated by the refinement of the CEM III pore network, as shown by the electrical resistivity results discussed earlier. In this connection, drying seemed to affect the CEM III more than the CEM I grout. This may be attributable to the greater propensity of slagbearing cement to develop shrinkage cracks at high temperatures and low relative humidity $(35,37,38)$. That notwithstanding, the findings show that the CEM III grout exhibited lower long-term effective porosity than the CEM I material.

The penetration of water under pressure is a test (29) recommended in Spanish Structural Concrete Code EHE-08 (30) to measure water permeability in concrete. The code also establishes a series of maximum depth values, depending on the type of environment to which the concrete is exposed. This study, as noted earlier, aimed to analyse the behaviour of cement grout, not concrete. That notwithstanding, as explained above, this test was conducted because the codes and standards on soil anchors and micropiles $(2,4)$ explicitly provide that grout must be EHE-08-compliant (30). The test findings showed that grout CEM III had lower maximum and mean penetration depths than CEM I at all the $\mathrm{w}: \mathrm{c}$ ratios studied in both the 28- and 90-day specimens. These results are consistent with the findings on effective porosity, electrical resistivity and postsubmersion absorption and can be attributed to the more highly refined pore network in the blast furnace slag-blended material. The Structural Concrete Code EHE-08 (30) also specifies that for exposure classes IIIa, IIIb, IV, Qa, E, H, F and Qb (for bulk or reinforced members), the maximum penetration depth must be lower than $50 \mathrm{~mm}$ and the mean lower than $30 \mathrm{~mm}$, requirements that were met by all the grouts studied here (see Figure 5). For exposure classes IIIc, Qc and Qb, in contrast (applicable to prestressed members such as soil anchors only), the code (30) stipulates that the maximum penetration depth must be under 30 and the mean under $20 \mathrm{~mm}$. All the grouts studied here also met these specifications, with the exception of the CEM I materials with a w:c ratio of 0.55 (see Figure 5), whose mean depth was higher than the ceiling value.

Chloride resistance in grout is an area of particular interest, since these ions are among the most aggressive corrosion inducers in reinforcement embedded in micropiles and soil anchors, particularly in marine environments or structures in contact with high chloride- or sulfate-content water. In the present study, this property was analysed in terms of the steady state chloride diffusion coefficient, found indirectly from electrical resistivity data (31). This coefficient was lower, as a rule, in the CEM III than in the CEM I grout (see Figure 6), with a few very early age exceptions. These findings are likewise consistent with the results of the other parameters 
studied. Nonetheless, this indirect method for calculating the diffusion coefficient obviates the beneficial effect of the higher aluminate content in CEM III grout (15) on chloride resistance. These aluminates, formed as a result of the hydration of the high $\mathrm{Al}_{2} \mathrm{O}_{3}$ content in blast furnace slag, react with chlorides to form chloraluminates, thereby preventing ion diffusion across the material (15). On those grounds, CEM III chloride resistance may be expected to be even higher than estimated here.

The results observed for the properties related to durability studied consequently appear to indicate that the grout prepared with cement carrying a high slag content affords greater soil anchor and micropile durability than portland cement grout. Indeed, in the 28-day specimens, all the CEM III grouts studied had similar or lower effective porosity, depth of water penetration under pressure and steady state chloride diffusion coefficients than the CEM I grout with a w:c ratio of 0.4 . This finding could have practical consequences, since the Spanish guide for designing and building soil anchors in road works (4), for instance, stipulates that the cement grout used for anti-corrosion protection in contact with reinforcing steel (i.e., the grout used other than in the fixed anchor) should be prepared with a w:c ratio of no greater than 0.4 to limit the amount of free water. Based on the present findings, CEM III grout with w:c ratios of up to 0.55 could prove to be not only apt for the protective purpose laid down in the code, but to deliver higher performance than CEM I grout with a w:c ratio of 0.4 .

\subsection{Compressive strength}

Compressive strength is the main parameter used by codes and standards (1-5) to ascertain whether a given type of cement is apt for use in soil anchors and micropiles. In both 7- and 28-day cylindrical and prismatic specimens, grout CEM I exhibited higher compressive strength than CEM III (see Figure 7). This finding was foreseeable, given the higher strength class of CEM I (52.5 MPa) than CEM III $(42.5 \mathrm{MPa})$. Moreover, strength gain in slag-blended cement is known to be slower than in portland cement $(7,28)$, requiring more time to reach comparable strength values. In addition, the CEM III studied here has low initial strength. Despite these considerations, the difference in 28-day strength between the two types of cement was not overly large.

While the legislation on micropiles (1-3) establishes certain minimum compressive strength values, the codes on soil anchors $(4,5)$ leave this decision to the designer's discretion. Spanish and European codes on micropiles $(2,3)$ call for a 28 -day (or the age when the micropile is loaded, if prior to that time) compressive strength of at least $25 \mathrm{MPa}$ in cylindrical specimens. All the grouts studied here complied with that requirement, except the CEM I and CEM III materials with a w:c ratio of 0.55 . The US manual FHWA-SA-97-070 (1), in turn, stipulates that 28-day strength in 5-cm cubic specimens must lie between 28 and $35 \mathrm{MPa}$. Item 2.7 above discusses the possible justification for considering the compressive strength observed for the 4-cm square, 16-cm deep semi-prisms tested here as a valid reference for the values that would be obtained with 5-cm cubic specimens. A comparison of the findings for the aforementioned semi-prisms to the FHWA-SA-97-070 (1) compressive strength requirement reveals that all the grouts studied would be code-compliant (the minimum strength recorded was $37.5 \mathrm{MPa}$ for CEM III with a w:c ratio of 0.55 ).

Lastly, although the 28-day strength was lower in the grouts prepared with cement containing a high proportion of blast furnace slag than in the portland cement grouts, most of the former group would comply with the requirements laid down in the applicable codes and standards. Nonetheless, if design specifications call for compressive strength greater than such minimum values, and blast furnace slag cement grout (in which strength gain is slower) is to be used, the micropiles or soil anchors concerned should be loaded at a later age, depending on the w:c ratio applied.

\section{CONCLUSIONS}

The main conclusions that can be drawn from the present findings are listed below.

- Further to the electrical resistivity and postsubmersion absorption findings for hardened grout designed for micropiles and soil anchors, when made from cements with a high blast furnace slag content the material has a more refined pore network than when prepared with a comparable portland cement.

- Slag-blended cement grout exhibits more favourable long-term durability properties than portland cement grout. In 28-day and older specimens, all the CEM III grouts prepared within the range of $w: c$ ratios studied have similar or lower effective porosity, depth of water penetration under pressure and steady state chloride diffusion coefficients than the CEM I grout with a w:c ratio of 0.4 .

- Most of the grouts prepared with slag-bearing cement meet the compressive strength requirements laid down in the various codes and standards for micropiles and soil anchors, whether measured on $15-\mathrm{cm}$ diameter, $30-\mathrm{cm}$ high cylindrical specimens or 4-cm square, 16-cm deep prismatic specimens. Their 28-day strength is, however, lower than observed for the portland cement grouts. 
- Cement grout for micropiles and soil anchors made with high blast furnace slag content cement can develop suitable mechanical strength and durability after hardening for a specified time.

\section{ACKNOWLEDGEMENTS}

This research was funded by the Spanish Ministry of Economy and Competitiveness (formerly by the Spanish Ministry of Science and Innovation) and FEDER through projects BIA2010-20548 and BIA2011-25721. The authors wish to thank Cemex España, S.A. and Cementos Portland Valderrivas, S.A. for supplying the cement used in this study, and CONSULTECO, S.L. for the use of its facilities for performing the compressive strength and penetration of water under pressure tests.

\section{REFERENCES}

1. Armour, T.; Groneck, P.; Keeley, J.; Sharma, S. (2000) Micropile design and construction guidelines Implementation manual report FHWA-SA-97-070, Federal Highway Administration - US Department of Transportation, Vancouver.

2. Dirección General de Carreteras (2005) Guía para el proyecto y la ejecución de micropilotes en obras de carretera, Ministerio de Fomento, Madrid.

3. Asociación Española de Normalización y Certificación (2006) Ejecución de trabajos geotécnicos especiales. Micropilotes. Norma UNE-EN 14199, Madrid.

4. Dirección General de Carreteras (2001) Guía para el diseño y la ejecución de anclajes al terreno en obras de carretera, Ministerio de Fomento, Madrid.

5. Asociación Española de Normalización y Certificación (2001)Ejecución de trabajos geotécnicos especiales. Anclajes. Norma UNE-EN 1537, Madrid.

6. Bijen, J. (1996) Benefits of slag and fly ash, Constr. Build. Mater. 10 [5], 309-314. http://dx.doi.org/10.1016/ 0950-0618(95)00014-3.

7. Geiseler, J.; Kollo, H.; Lang, E. (1995) Influence of blast furnace cements on durability of concrete structures, $A C I$ Mat. J. 92 [3], 252-257

8. Bouikni, A.; Swamy, R.N.; Bali, A. (2009) Durability properties of concrete containing $50 \%$ and $65 \%$ slag, Constr. Build. Mater. 23 [8], 2836-2845. http://dx.doi.org/10.1016/j. conbuildmat.2009.02.040.

9. Wiebenga, J.G. (1980) Durability of concrete structures along the North Sea coasts of the Netherlands, $A C I$ Publications Sp-65, 437-452.

10. Jau, W.C.; Tsay, D.S. (1988) A study of the basic engineering properties of slag cement concrete and its resistance to seawater corrosion, Cem. Concr. Res. 28 [10], 1363-1371. http://dx.doi.org/10.1016/S0008-8846(98)00117-3.

11. Thomas, M.D.A.; Scott, A.; Bremmer, T.; Bilodeau, A.; Day, D. (2008) Performance of slag concrete in marine environment, ACI Mat. J. 105 [6], 628-634.

12. Manmohan, D.; Mehta, P.K. (1981) Influence of pozzolanic, slag and chemical admixtures on pore size distribution and permeability of hardened cement pastes, Cem.Concr. Aggr. 3 [3], 63-67.

13. Baroghel-Bouny, V. (2007) Water vapour sorption experiments on hardened cementitious materials: Part I: Essential tool for analysis of Hygral behaviour and its relation to pore structure, Cem. Concr. Res. 37 [3], 414 437. http:// dx.doi.org/10.1016/j.cemconres.2006.11.019.

14. Sánchez, I.; López, M.P.; Climent, M.A. (2007) Effect of fly ash on chloride transport through concrete: Study by impedance spectroscopy, en: Beaudoin, J.J., Makar, J.M.,
Raki, L. (eds.) Durability and Degradation of Cement Systems: Corrosion and Chloride Transport; T4.04-4. Proc $12^{\text {th }}$ International Congress on the Chemistry of Cement, National Research Council of Canada, Montreal.

15. Leng, F.; Feng, N.; Lu, X. (2000) An experimental study on the properties of resistance to diffusion of chloride ions of fly ash and blast furnace slag concrete, Cem. Concr. Res. 30 [6] 989-992. http://dx.doi.org/10.1016/ $\mathrm{S} 0008-8846(00) 00250-7$.

16. Asociación Española de Normalización y Certificación (2000) Cemento. Parte 1: Composición, especificaciones y criterios de conformidad de los cementos comunes. Norma UNE-EN 197-1, Madrid.

17. Asociación Española de Normalización y Certificación (2005) Cemento. Parte 3: Determinación del tiempo de fraguado y de la estabilidad de volumen. Norma UNE-EN 196-3, Madrid.

18. Asociación Española de Normalización y Certificación (2005) Métodos de ensayo de cementos. Parte 1: Determinación de resistencias mecánicas. Norma UNE-EN 196-1, Madrid.

19. Asociación Española de Normalización y Certificación (2001) Ensayos de hormigón endurecido. Parte 2: Fabricación y curado de probetas para ensayos de resistencia. Norma UNE-EN 12390-2, Madrid.

20. Polder, R.; Andrade, C.; Elsener, B.; Vennesland, O.; Gulikers, J.; Weidert, R.; Raupach, M. (2000) Rilem TC 154-EMC: Electrochemical techniques for measuring metallic corrosion - Test methods for on site measurement of resistivity of concrete. Mater. Struct. 33 [234], 603-611. http://dx.doi.org/10.1007/BF02480599.

21. Asociación Española de Normalización y Certificación (2008) Durabilidad del hormigón. Métodos de ensayo. Determinación de la resistividad eléctrica. Parte 2: Método de las cuatro puntas o de Wenner. Norma UNE 83988-2, Madrid.

22. Lübeck, A.; Gastaldini, A.L.G.; Barin, D.S.; Siqueira, H.C. (2012) Compressive strength and electrical properties of concrete with white Portland cement and blast-furnace slag, Cem. Concr. Comp. 34 [3], 392-399. http://dx.doi. org/10.1016/j.cemconcomp.2011.11.017.

23. American Society for Testing Materials (ASTM) (1990) ASTM Standard C642-90: Standard test method for specific gravity, absorption, and voids in hardened concrete, Philadelphia.

24. Asociación Española de Normalización y Certificación (2008) Durabilidad del hormigón. Métodos de ensayo. Determinación de la absorción de agua por capilaridad del hormigón endurecido. Método Fagerlund. Norma UNE 83982, Madrid.

25. Rilem (1999) Rilem recommendation TC 116-PCD: Permeability of Concrete as a Criterion of its Durability. Mater. Struct. 32 [217], 174-179.

26. Asociación Española de Normalización y Certificación (2008) Durabilidad del hormigón. Acondicionamiento de muestras de hormigón para los ensayos de permeabilidad a gases y capilaridad. Norma UNE 83966, Madrid.

27. Punkki, J.; Sellevold, E.J. (1994) Capillary suction in concrete: Effects of drying procedure, Nordic Concrete Research Publication 15, [2/94].

28. Ortega, J.M.; Sánchez, I.; Climent, M.A. (2013) Influence of different curing conditions on the pore structure and the early age properties of mortars with fly ash and blastfurnace slag. Mater. Construcc. 63 [310], 219-234. http:// dx.doi.org/10.3989/mc.2012.06111.

29. Asociación Española de Normalización y Certificación (2009) Ensayos de hormigón endurecido. Parte 8: Profundidad de penetración de agua bajo presión. Norma UNE-EN 12390-8, Madrid.

30. Comisión Permanente del Hormigón (2008) Instrucción de Hormigón Estructural EHE-08, Ministerio de Fomento, Madrid.

31. Andrade, C.; Alonso, C.; Arteaga, A.; Tanner, P. (2000) Methodology based on the electrical resistivity for the calculation of reinforcement service life, en: Malhotra, V.M. (ed.) Proc. $5^{\text {th }}$ CANMETIACI International Conference on 
Durability of Concrete, Supplementary papers, 899-915, American Concrete Institute, Barcelona.

32. Asociación Española de Normalización y Certificación (2003) Ensayos de hormigón endurecido. Parte 3: Determinación de la resistencia a compresión de probetas. Norma UNE-EN 12390-3, Madrid

33. Osterminski, K.; Polder, R.B.; Schieß1, P. (2008) Long term behaviour of the resistivity of concrete, Heron 53 [1], 59-78.

34. Cakir, O; Aköz, F (2008) Effect of curing conditions on the mortars with and without GGBFS, Constr. Build. Mater. 22 [3], 308-314. http://dx.doi.org/10.1016/j. conbuildmat.2006.08.013.

35. Neville, A.M. (1995) Properties of concrete, Pearson Education Limited, Harlow.
36. Kanna, V.; Olson, R.A.; Jennings, H.M. (1998) Eff ect of shrinkage and moisture content on the phy sical characteristics of blended cement mortars, Cem. Concr. Res. 28 [10], 1467-1477. http://dx.doi.org/10.1016/ S0008-8846(98)00120-3.

37. Chern, J.C.; Chan, Y.W. (1989) Effect of temperature and humidity conditions on the strength of blast furnace slag cement concrete, ACI Sp Publication, [114-67], 1377-1397.

38. Bao-Guo, M.A.; Xiao-Dong, W; Ming-Yuan, W; Jia-Jia, Y, Xiao-Jian, G. (2007) Drying shrinkage of cement-based materials under conditions of constant temperature and varying humidity, Journal of China University of Mining and Technology 17 [3], 428-431. http://dx.doi.org/10.1016/ S1006-1266(07)60119-9. 